\title{
Towards a more just world: an agenda for transformative heritage planning futures
}

\author{
Loes Veldpaus, Višnja Kisić, Eva Stegmeijer and Joks \\ Janssen
}

In this final chapter we address the key questions we consider to lie ahead for heritage planning, when pushing new practice and research frontiers. We build on and take forward the points made in Parts I and II, as well as discussions with authors and other heritage planning experts in academia and practice. We touch on those heritage issues that we believe could contribute to a more just, diverse and sustainable world. With this agenda, we aim to enrich and inspire both practice and research directions by suggesting new, combined, continued and alternative perspectives on doing, studying and reflecting on heritage planning. We focus on conceptual and thematic ways forward, supported by methodological, governance and funding considerations. There are many angles to be explored, numerous ideas to be shared and actions to be undertaken. This agenda is but a small contribution.

\section{Heritage planning and contemporary challenges}

Spatial planning operates in a world full of context: tabula scripta. Developing spatial policies, plans and designs for the future always requires interaction with pre-existing conditions: structures, creations, ideas, uses, values, pollutions and other historic layers. Engaging with them can be seen as a restriction, or as an opportunity to work with the potential of place. We would therefore argue that, conceptually, all spatial planning is a form of heritage planning. Conversely, heritage planning cannot be limited to what is formally designated or listed. As also discussed in the introduction to this book (Chapter 1), formal definitions of heritage, as for example used in European policy contexts, have become much broader over time (Veldpaus et al. 2019). 
Forging more direct links between heritage and planning in terms of policy and process has been one of the main items on the international agenda of heritage conservation in the twenty-first century. The relationship established between the two practices is more dynamic and increasingly aligned with wider societal challenges, such as sustainability and human rights agendas (e.g. CoE 2005; EU 2019; UNESCO 2011; UN-HABITAT 2016). While integrating with these wider agendas seems a logical step, the role that heritage planning could play in the context of the immense challenges our contemporary world is facing may feel insignificant. In the face of the climate breakdown, financial crises, growing wealth inequalities, social and spatial injustice, political radicalization and a global pandemic affecting, threatening and changing life across the world, one may easily wonder what heritage planning can really do to contribute to solving these problems. A whole lot, we think!

Heritage planning, we argue here, has a role in creating, addressing and tackling the various crises and associated challenges. The agenda presented in this chapter aims to challenge the foundations of heritage and planning as practices and disciplines, as well as their integration and their role(s) in wider agendas. As this book shows, current research in heritage planning tends to be largely focused on understanding the impact that diverse challenges have on (built) heritage, in order to then manage and mitigate these 'threats' for the sake of heritage safeguarding. However, there is also a visible shift towards research that considers the roles and impacts - both positive and negative - of heritage planning in addressing societal challenges.

As became evident in Part II of this book, various ideas are entering and changing heritage planning research and practices; for example, looking at the impact of the process of integrating heritage and planning domains, and deconstructing the idea that certain things are inherently heritage. Heritage definitions are becoming more inclusive, in response to long-standing critiques that heritage is too often about a very limited and defined set of buildings, voices and values (Dicks 2000; Hosagrahar et al. 2016). This comes with the reconceptualisation of heritage as an iterative process and practice of (re)selecting, (re)interpreting and (re)presenting the past, rather than defining heritage as (just) a material asset with aesthetic and historic value.

As this book illustrates, heritage planning is a highly contextual process which takes place within a setting of complex regulatory frameworks, institutional processes, practices, funding, political and policy priorities, at various spatial and governance scales. Risks, roles and responsibilities vary and change, as they move between private, public and other-than-public actors (Rex 2018; Veldpaus and Pendlebury 2019). This book also underlines both the delay and 
reciprocity between critique and change in the heritage and planning fields and highlights the need to move beyond the current focus on the 'how' of heritage planning. We need to also address what we intend heritage planning to do, and what it actually does, and to whom.

Our aim is to encourage wider, broadly engaged perspectives on heritage planning that contribute to addressing contemporary challenges in a comprehensive manner and enhance creative ways of knowing and doing. We do this by deepening and broadening the issues and questions that this book poses regarding its three pivotal themes: social, environmental and developmental perspectives in and on heritage planning. We question the dominant frameworks of governance and interpretation, highlighting alternative perspectives on them. We end by exploring the need to question the structures and frameworks that govern how we think and do our research and work in heritage planning today. Finally, at the core of the agenda we are proposing is the idea that heritage planning helps us pose questions that could be at the centre of diverse movements for making the world a more just, diverse and sustainable place.

\section{Social justice: beyond identity politics and the governance of inclusion}

Over recent decades, there has been increasing attention to the positive role heritage plays in societal dynamics like participation, cohesion and identity formation. Studies of these 'desirable' characteristics are widely called for and funded, making it more important to recognize that heritage can just as well be used to curate, police and destroy identities and communities (Anderson 1983; Hall 1999). Working towards social justice means we need to recognize these processes, and thus scrutinize our actions as researchers, practitioners, volunteers, donors and policymakers in the field. We need to be willing to change and leave behind some of those actions and ideas. Chapters in this book touch upon the importance of the societal and social dimensions in heritage planning, either through engaging with participatory processes and tools (e.g. Chapter 7 Micoli et al.; Chapter 15 Della Torre and Moioli) or by acknowledging the hidden, marginalized and not-so-obvious layers of heritage (Chapter 8 Fiorentini et al.; Chapter 14 Whyton and Perry). These examples show how heritage planning practice is reorienting itself, as well as how reflections from research can help with this process. Participation, of course, does not automatically lead to social justice, just as diversifying the heritage offer does not by definition create equality. Social injustices and inequalities are systemic 
and structural issues which are deeply rooted in both heritage and planning practices and policies. This is why, in the following paragraphs, we suggest topics and approaches that can help address these, without shying away from the tensions and contestations that arise along the way. We hope our questions will open up pathways towards a more just world.

\section{Co-governance: collaboration, participation, inclusion}

Even though expert-led decision-making remains the norm, especially in formal planning contexts, talk about civic engagement in heritage is growing, as is the number of experiments and initiatives in this area. In both policy and practice there is growing receptiveness to the idea of citizens emancipating themselves from being heritage consumers to being active partners, engaging in new interpretations of heritage. The road from desirable ideas to established practices is, however, not paved at all and is rutted with multiple future challenges and negotiations. Indeed, the questions and suggestions raised throughout the book, as well as in the interviews we have undertaken, address the processes of partnership and participation. They show the need for looking at the roles of expectations, collaborations and power relations; they underline the current lack of diversity in the field, as well as the (practical) challenges of participation and inclusion. A lot of these concerns come down to the question: how do we make participatory governance fundamental, valuable and ethical and not just the obligatory tick-box?

As argued by many, participatory processes, which come in many different shapes, forms and models, don't automatically make things better (Kaza 2006; Meléndez and Parker 2019; Song 2015). We can never include everyone and everything all the time, so it is important to be open and clear about expectations and aims for those processes, as well as the governance models used. Within the existing structures, we can ask who is willing and able to participate in the first place. Who 'allows' and 'tolerates', and who is being 'allowed' and 'tolerated' in the process? But also, to what degree are space, resources and funding accessible to and claimed by, for example, other-than-public and non-governmental organizations, citizens and community groups? There are of course also questions regarding the practical side to this; for example, how tools and technologies can support, define or impede processes of participation, plural interpretations and collaboration. By looking at the structural and institutional capacities and arrangements, we may be able to change procedures too. All of this would require institutional and policy change, and reconsidering everyday routines, practices and procedures. 
Power relations are important here, and we can learn from available work on co-governance, community organizing (e.g. Cahuas 2019; Emejulu 2011) and urban commons (e.g. Dellenbaugh et al. 2015; Foster and Iaione 2015). This includes research on the ethics of co-governance and participatory processes; how they construct and deny identities and heritage meanings and how they can be fair and sustainable. We can also learn from models of dealing with conflict and contestation within co-organizing and co-governance arrangements, which could involve looking at consensus- or competency-led governance, as well as resistance, activism and protest as valid forms of participation. Practising and researching the 'refusal to participate', for instance, and having the right not to share or negotiate legacies, practices and heritages is another line we could be exploring (Salt 2020). Because what else is there, when the context you are in denies or threatens your very being? It would be helpful to (further) develop collaborative practices between practice and research, and learn from each other, by being involved in each other's worlds and reflecting on them. This could be done through embedded, ethnographic, co-creative work, reflective workshops or action-research methods, as well as through working cross-boundary, using visual, archival, social, archaeological, technical and medical research, and critically exploring intersections and implications. In all this work, it will be important to consider our own positionality in collaborations, and not construct ourselves outside of them.

\section{Embracing dissonance: exploring plural interpretations and contestations}

As Hall (1999) tells us, preserving things of value for posterity has always been related to the exercise of power, in which specific things are foregrounded just as other episodes and perspectives are forgotten. The selections, understandings and interpretations of heritage, and whether and how these embrace dissonances and plurality, are thus challenges closely related to participation and co-governance. Planning and redesigning our environment involves selecting and reusing some objects, structures and pasts, while ignoring and even literally paving over others. Neither planning and heritage, nor their participatory processes, are innocent bystanders in this. In caring for some future worlds by selecting and safeguarding some pasts, we colonize or impede other possible future worlds. As a process of selecting and mobilizing pasts for future-oriented purposes, heritage planning can always be used in many ways, and is thus always contested.

Dealing with different, contesting interpretations of heritage and mobilizations of history has been extensively discussed in heritage literature (Kisić 2016; Silverman 2010; Tunbridge and Ashworth 1996). So has the need for 
recognition of layers of the past that might be shameful or painful (Light 2000; Macdonald 2010; Salt 2020; Sinclair-Chapman 2018). We can pose similar questions in the context of heritage planning, and question its relationship with these concepts. Strategies aimed at 'governing' plurality and dissonance in effect often create closures rather than openings. As argued by Kisić (Chapter 2 ), they often work towards consent and compromise, rather than acknowledging difference and plurality. This can be a form of silencing that can actually make heritage more toxic (Wollentz et al. 2020). The planning context adds to this challenge, as heritage is often seen as only a small (obstructive) element to deal with while one is also having to negotiate economic interests and a raft of regulations, conditions and actors within and outside of heritage. The presentation and interpretation of histories in built heritage, spatial planning and public space is often very limited and unnuanced, erasing any plurality. Interpretations tend to get reduced to an interpretation board, plaque, map or tour, although there are inspirational examples of 'alternative' narratives, and materials pluralizing interpretations and guides (e.g. Pitts 2019; Tosch 2013).

Therefore, understandings of dissonance, plurality and restorative justice need further discussion, exploration and action in the context of heritage planning, as has become clear throughout this book, and far beyond in urgent societal debates such as the \#BLM and \#MeToo movements. We do observe a growing awareness in the heritage field of the plural (and often conflicting) layers and meanings of heritage. However, as Kisić (2018) argues, heritage dissonance should not be practised solely in a context where heritage is currently tagged as 'difficult', 'contested' or 'dissonant'. It has to be acknowledged in issues of latent conflicts, silenced voices and epistemic injustices embedded in heritage that is deemed normal and unproblematic. Acknowledging dissonance can help question the often strictly policed heritage narratives, practices and place delineations that are followed in heritage planning, and their rootedness in discourses of ethnicity, nation, centre-periphery, class divisions, gender relations and migrations, among others (Kisić 2018). This can enable us to notice, learn from and deal with the different ways of being, using, remembering, feeling and responding to and in place. Finally, it can pave the way for agonistic approaches (Mouffe 2013) in which conflictual views, positions and interests are deliberated and negotiated openly.

There are many questions that can guide future work, and touch on the relations between heritage and politics in a plural world. What does it mean that interpretation in heritage planning - and thus the historic environment - is still very much curated by a few experts? Whose interpretations are labelled as 'legitimate', and whose as 'informal' or 'alternative'? Who listens, chooses or decides when there are plural and conflicting interests? How do connection, 
confrontation or annihilation work in heritage planning, making different historic experiences (in)visible in public spaces? How do we negotiate place-based versus on-the-move histories and heritages; for example, those of travelling communities, migrants, pilgrims, or indeed the homeless or sans papiers (see also Chapter 8 Fiorentini et al.)? What role can heritage planning play in restorative justice work when it comes to reckoning with the pasts of, for example, the slave trade, various genocides, patriarchy, colonialism or fascism? These questions mean we need to position heritage planning in the context of wider injustices and debates and acknowledge its role in both creating and addressing them. Of course, doing so will open up many more questions, both in practice and research.

\section{Environmental justice: beyond sustainability and climate emergency}

Global and local issues around climate change, environmental justice and sustainability are ever more pressing and they will become even more central to decision-making in heritage planning. Much of the current research that connects heritage and climate focuses on developing mitigation strategies to help 'save' heritage through risk assessment, monitoring and protection mechanisms (see also Chapter 11 Spizzichino and Margottini; Chapter 12 De Angeli and Battistin). Consequently, the concepts of vulnerability and mitigation are at the forefront of today's heritage planning. However, the understandable impulse to pursue mitigation strategies to protect heritage from climate change must be complemented by scenarios of adaptation or even of 'curated decay' and letting things go (DeSilvey 2017).

Between and beyond the current approaches of mitigation and adaptation are a myriad of other practical possibilities and planning and design interventions, as well as many more fundamental questions we could pose. One line of thinking is on how we can respect and learn from historic structures and civilizations (Chapter 5 Moore and Tully), from different knowledge and value systems and from different worldviews, for example those of indigenous peoples. Such conceptualizations and mobilizations of pasts, presents and futures have to do not only with greening, reusing and adapting, but also with challenging the anthropocentrism of current research, practice and policy (Erickson 2020). 
Sustainability and climate change: socio-environmental gain and loss

The way we deal with heritage in the complex context of climate change, with its many feedback loops, automatically leads to questions about continuity, change and loss. Considerations on what we preserve and why are magnified in the face of climate change. And what about the heritage of climate change? It is not possible or desirable to protect all heritage from climate change, bearing in mind that heritage planning is also contributing to climate change. Moreover, mitigation and protection to save material assets can have significant impacts on local communities, indigenous peoples and minority groups (e.g. Carter 2010; Kimmerer 2020). What and who is considered worth saving, heritage or people (or other-than-human life) is, of course, not neutral. In this vast and tangled web of political choices, questions of environmental, social and economic (in)justice are everywhere; thus, these are questions of power.

As decision-makers declare climate emergencies while frequently allowing the demolition of existing buildings in order to build new ones at unprecedented speed, heritage planning also provides mechanisms to encourage sustainability. Continued use or (adaptive) reuse of historic elements helps in 'reducing, reusing or recycling' material waste and containing the embodied energy of materials and labour (see also Chapter 3 Van Balen and Vandesande). This is also partly why there is an increased focus on adaptive reuse in heritage planning policies in the EU and many European countries (Veldpaus et al. 2019). This stimulates us to think about how we care for material worlds. Can we consider material heritage and culture as circular, non-depleting resources? When we reduce environmental impacts through sustainable and adaptive reuse, how do we address the underlying choices, in terms of whose history, heritage and environments are considered valuable enough to keep?

Moreover, as experts worldwide agree that we must quickly deploy vast resources to mitigate and adapt to global warming, we should also think about who this affects and in what ways. Think about, for example, the energy transition; building solar and wind farms across land- and seascapes, along with (inter)national and regional grids to connect them. This creates communities, heritage, archaeology and cultural landscapes as much as it disturbs them. Who gets to benefit from this 'greening' of energy, and will this new layer revalue or devalue the landscapes it is added to? These are just a few questions on the intersections with the energy sector, which could just as well be asked for transportation, agriculture, building and manufacturing, amongst other land uses. 
Climate change measures do have a tendency to reinforce existing social and economic inequalities (Davoudi et al. 2019; Erickson 2020). How can we make sure they don't lead to increased inequality, displacement, poverty, gentrification and the de-identification of heritage? This needs interdisciplinary and collaborative work on the mutual, sometimes conflicting, relationships between social, economic and environmental values and needs. And we should not be afraid to ask difficult questions. What is the role of heritage in contributing to climate change, to environmental injustices, directly or indirectly; for instance, reliance on tourism and travel? Which (and whose) heritage are we willing to 'sacrifice' for climate-friendly solutions? How do the social and the environment parts of sustainability interact and play out in heritage planning? Where and who benefits from protecting heritage from climate change, and who is being displaced or made homeless through extreme weather events? Which parts of the world are thought of as pristine and protected, and which will be 'allowed' to become 'wastescapes', facing massive pollution, or flooding or overheating issues? And what happens to the heritage of climate refugees? But also, are solar and wind farms only acceptable in landscapes that do not have legal protection mechanisms, which are peripheral or populated by people with fewer resources? Is the PR side of 'good government' or corporate social responsibility regarding climate goals being pursued at the expense of other global challenges such as fighting poverty and racism? We are convinced that heritage planning has the capacity to embrace both social and environmental justice (Agyeman 2005).

\section{From risk reduction and adaption towards transformative practices}

Much heritage planning research and practice focuses on trying to reverse or mitigate the impacts of climate change, as well as understanding and increasing the existing social and economic resilience of heritage places and their communities in the face of accelerating changes (see Chapter 11 Spizzichino and Margottini; Chapter 12 De Angeli and Battistin). Building on this work, we argue that many additional factors could be considered or combined when considering exposure to and impacts of threats, such as the involved communities, the vulnerability of heritage sites and the adaptive capacity of decision-makers involved. Can more accurate risk assessments be developed if such site-specific conditions are also considered, in addition to, for example, proximity to hazards? The integration of heritage and climate research and climate policies is essential for this. This involves promoting heritage-specific knowledge, skills, methods and tools, but also bringing together critical thinking and new conceptualizations as developed in both fields. Mainstreaming heritage in climate decision-making, and vice versa, starts with speaking each 
other's language and understanding and openness to perceptions and critiques, to join up and develop our thinking and doing.

In addition to better informed and integrated preventive risk management and adaptation strategies, we argue that future heritage planning could also pursue more radical and creative transformations. As Kisić argues (Chapter 2), we should challenge nature-culture divides and look to other existing regimes of meaning-making and cultural significance (e.g. Dabiri 2020; Kimmerer 2020). The historic environment is a vast knowledge resource that has its own capacity to resist or adapt to climate change (see e.g. Chapter 10 Vallerani and Visentin). This stimulates revisiting our ways of dealing with the (natural) world and our (human) relation to and position in it, and reimagining the spaces we operate in. What would it mean, for example, to consider buildings or spaces not occupied by humans as more than vacant, brownfield, empty or green (Lowenhaupt Tsing 2017)? Can we think of a world beyond saving, or care without conservation, as DeSilvey (2017) asks? Do we dare to leave environments unplanned, allowing not only for re-wilding or re-wetting, but for non-human life to flow in unforeseen directions?

To achieve environmental justice requires structural change in heritage planning. It is simply not enough to just 'adjust' and 'mitigate'. We could imagine radically different post-fossil fuel futures, and take seriously worldviews that engage with indigenous knowledges, past societies or literary fiction. This implies different ways of conceptualizing, engaging with and thinking about life on earth and our environments, and thus our understandings of heritage, climate breakdown and sustainability. It then also encourages further and maybe unexpected collaborations, bridging between different ways of knowing and doing, between different worldviews and approaches. Heritage planning is a platform where many of those worlds can come together; as such it could lead in developing more integrated approaches with relevance way beyond its field.

\section{Economic justice: beyond a means to an end for heritage planning and development}

Throughout this book the emphasis has been on the ongoing integration of heritage into wider planning schemes, often accompanied by economic development objectives. As various chapters in this book show, integrating heritage and planning policies brings advantages. For example, it provides a base for dynamic, continued use, maintenance and care (see Chapter 1 Stegmeijer et al.); and it contributes to (regional) development objectives like skills devel- 
opment, creating jobs, involving communities and local food production (see Chapter 3 Van Balen and Vandesande; Chapter 15 Della Torre and Moioli; Chapter 16 Sjölander-Lindqvist et al.). Other chapters show that heritage-led regeneration can lead to exploitation of heritage for (private) profit, and facilitates if not instigates processes of gentrification, commodification and privatization of urban and rural commons (see Chapter 6 Veldpaus and Wacogne; Chapter 13 Sjölander-Lindqvist). Each of these chapters in their own way indicate that we should look at both the positive and negative impacts, at the intended and unintended results, of the alliance between heritage and planning and development policies.

This also reiterates that heritage is 'for' something; that it is used as a means to an end. Thus, when integrated into development-oriented policies, heritage is probably expected to facilitate a particular vision of development. This is visible in many (built) heritage policies which promote heritage as a positive force in society, contributing to fostering urban regeneration and economic development by being a (soft) location factor, attracting investment, bringing in visitors and improving spatial quality and quality of life, wellbeing and social cohesion. As much as the integration of heritage and planning benefits certain people and places, the same schemes can adversely impact the livelihoods and quality of life of others. Problems of inequality, erasure and dislocation need to be confronted much more rigorously. We need to address the role of heritage in achieving different policy objectives, in order to come up with alternatives. For this, we argue, we have to start thinking about heritage not simply as a means to an end, but as an actor that shapes our world.

\section{Challenging commodification and growth: alternatives to market-driven heritage development?}

Over the last few decades, heritage planning has played a crucial role and made a substantial contribution to the (economic) development of places and landscapes. Throughout Europe, many buildings and vacant (post-industrial) spaces have been rehabilitated and refurbished into lively, mixed-use urban quarters. Since the 1990s, the aims to boost city economies and to creatively reuse heritage have very much aligned. Conservation and real estate development have become partial to each other. In many instances, the main reason for reuse will be profitability. Profit can be formulated rather narrowly, in money cashed by a developer or investor; or more broadly, as part of a long-term community interest in the socio-economic potential of a place. Whether profit is narrowly or broadly formulated, the heritage sector in many countries, in its effort to become central to discussions on regeneration, economic develop- 
ment and planning, has become - and was pushed to be - strongly reliant on financial and market incentives as drivers for heritage conservation.

The context of growth pressures easily turns heritage into a commodity, although it could also be considered a 'commons', a public good (see also Chapter 2 Kisić). Consequences such as commodification, touristification, gentrification and privatization brought about by heritage planning are often still seen as mostly positive. Land value goes up, investments and developers' attention are triggered, and the material heritage and a certain 'character of place' can be retained through those mechanisms. However, when the integration of heritage and planning is predominantly driven by growth narratives, heritage assets and narratives selected are more likely to be the ones that are 'useful' in creating economic gain. When only the 'useful' histories are mobilized, many other histories are forgotten, including the layers, perspectives and voices that aren't seen as worth listening to in the process of commodification (Veldpaus and Pendlebury 2019). Seen this way, heritage can be a clear tool in the process of gentrification; not just by making places unaffordable, but also by denying connections to place to those who are not included in the 'useful' histories. It would be interesting to look further into how (cultural) appropriation works in heritage planning, when there is an interest in highlighting so-called alternative or marginalized heritage narratives. All this of course affects both the material and immaterial reality in terms of what is selected to be restored, reused, reiterated, redesigned, and ultimately, seen as heritage. We can also wonder, if concepts such as 'place character' or 'place identity' are ways of using heritage, while staying away from 'formal' protection mechanisms? Or do they more effectively bring a broader variety of heritage into planning realms than could ever be done through formal listing and protection?

It is also relevant to look into how heritage listings and accompanied funding and visitor streams favour (further) growth of particular cities and regions, while other places 'that don't matter' (Rodríguez-Pose 2018) do not get to benefit in the same way. Selected regions get support in reusing their heritage buildings and landscapes, and attract more inward capital and talent, further enhancing their positive stance towards some heritage. Other regions are forgotten and risk losing their diversity in heritage. The process feeds back upon itself, creating a self-perpetuating cycle with little space for reflection on meanings and uses of heritage on either side. How can heritage planning counter these effects and take uneven development more seriously?

One way could be by deeper exploration of alternatives to market-driven development and pro-growth objectives. For example, learning from scholarship on alternative governance and management models, ideas of 'tourism 
degrowth', voicing the critique of (urban) over-tourism in popular destinations and selling cities as tourism commodities (Milano et al. 2019). Or perhaps following Ferreira and Schönfeld (2020) to explore what it means when economic growth and capital accumulation are not positioned centre stage in planning. Furthermore, we could engage with ideas on commons (Ostrom 1990), the 'right to the city' (Harvey 2003), collaborative planning (Healey 1997) and community organizing (e.g. Banks and Westoby 2019) to alter the way heritage planning is understood and done. Heritage-as-commons could offer a way to resist and disrupt the increasing production of heritage as commodity, open up new possibilities for pluralizing alternative ownership and stewardship (Pantazatos 2015), and enhance the shared care for, and production of, heritage. We should explore and counter dominant narratives of government-led and market-driven heritage conservation, and rethink heritage management frameworks based on property, profit and growth. This also means that we need to find, test, develop and normalize alternative legal, financial and governance models.

\section{Heritage as an actor shaping our worlds}

In the introduction to the book we suggest that 'heritage' as a field moves between being a sector, a factor and a vector in relation to planning. Building on this conceptualization of heritage in planning and the issues set out above, we argue that there is a need for research and practice that understands heritage as an actor. This is not about simply adding a fourth approach to how we deal with heritage in planning, but about fundamentally reconceptualizing what heritage is and does. It assumes that not only do we do things with and to heritage; heritage itself also does things with and to us. Heritage is an actor in the environment, and thus in daily life, as much as in conservation planning assemblages. Heritage is not (only) something to care for; it also cares for us (or not), and through it we can care for others.

Although this may not be a common way of thinking about heritage in the heritage planning context, it certainly isn't new. The idea of heritage-as-actor builds on the heritage theory which argues that heritage is performative. It is made to 'do' things. So, whether it is put to work for wellbeing, urban development, tourism or other aims, it is (re-)enacting, (re)producing and mobilizing selective past(s) (Davidson 2016; Ugwuanyi 2020; Wong 2013) and often doing many other unplanned and unintended things. Moreover, it resonates with what has been coined the 'affective turn' in heritage studies (Crooke and Maguire 2018; Tolia-Kelly et al. 2017), showing how affect and emotions influence our dealings (and doings) with heritage and how heritage is affective and emotive (Buchczyk and Facer 2020). This is not just a theoretical debate, as 
we discussed above. Heritage creates atmospheres and evokes feelings in public places, and we know that the same heritage moves people in very different ways.

So, instead of seeing heritage as a means to an end, or as a goal in itself, we propose to see it as an actor. That way, we can move beyond 'using' heritage to interacting with it and recognizing its agency. The main aim of proposing this is to redirect the thinking about the processes we engage in as researchers and practitioners. Heritage is often promoted as a positive force in society that can improve quality of life; for example, through improved wellbeing and social cohesion. We should, however, ask, who is it doing these things for and to? Whose wellbeing is being cared for, through caring for this heritage? It is hard to imagine, for example, that the celebration of a slaver in a public space is good for the wellbeing of those who are direct descendants of enslaved people. This dynamic should be taken into account when pursuing 'wellbeing' or 'cohesion' agendas in heritage policy and action. In trying to make environments more inclusive and accessible, we should look at what heritage does, intentionally and unintentionally, and how this puts up not just physical barriers, but also social, psychological and emotional ones.

This forces us to take a new look at the relations and networks that are constantly (re)created between heritage, people and environments, and between people through heritage, and between people and heritage through policies. Heritage planning can be seen as a way of caring for heritage, and thus of caring for people's wellbeing through heritage, in terms of quality of life, social cohesion and belonging. Framing it this way might make us think through the ethics of these acts of caring for, about or through heritage. Caring, conserving, planning; none of those activities - however well meant - are inherently good, and we have to be aware of the social and political functions they perform (Ahmed 2017; Puig de la Bellacasa 2017). This happens in the everyday: in how we see our environment, in the use of space. It is part of maintenance and demolition, and deliberate or careless appropriation or dismissal of certain spaces, practices, symbolisms and narratives. It asks for a willingness to engage with more comprehensive understandings of history and thus heritage, thus engaging with conceptualizations, models and approaches that exist in different geographical, theoretical and sectoral contexts. We should also consider the methods we use, and address methodological whiteness (Bhambra 2017) and wilful indifference (Virdee 2019) to open up spaces for new questions, approaches and knowledges. 


\section{Agenda making: reflecting on practice and research}

Heritage planning, understood as dealing with the layered, multifaceted material and immaterial histories of places and people in local and regional planning contexts, can help to sustain a more liveable future for everyone. In this final chapter, we have argued that heritage planning could be relevant to several movements for making our future world more just, inclusive and sustainable. As practitioners and academics, we always strive for betterment in some way, but better for whom? Who benefits from our actions? Are we willing to listen, to be critical and to change our current repertoire of doing research or making policy? With daunting environmental, societal and economic challenges ahead, we will have to reach beyond the comfort of our disciplines and worldviews, and ask questions related to the frameworks within which our work and research operates, our own roles and the wider impacts of heritage planning.

As this book shows, the heritage planning assemblages are dynamic, and their processes and outcomes are fluid. They need to be understood and reflected on in context, in depth and in time. In addition to understanding this complexity, we need to confront some of the (hidden) assumptions and mechanisms that structure the reality of contemporary heritage planning - within and beyond the field. This means we need to look both at how to align heritage and planning better, and at what the processes and politics involved in this integration do. We need to look at formal and informal heritage concepts, structures, practices and traditions; how they are, or are not, being used to inform planning and design processes, policies or practices, and vice versa. Who benefits from the 'added value' of integrating heritage with planning? How can heritage planning drive and enable our striving for a better future?

Besides (re)assessing the institutional and theoretical frameworks of heritage planning, we need to look at frameworks that shape knowledge creation, dissemination and consumption. These include the influence of neoliberal science policy and management, for example, on the methods, organization and content of research (Lave et al. 2010); the rise of the entrepreneurial university, which leads to the commercialization and fortification of knowledge (Lynch 2006); and the project-form as a form of thinking, packaging and doing research (Pavićević and Spasića 2016). Funding for both research and practice tends to come with narrow agendas, privileging work that happens in and on certain places, and focuses on the wishes of the payers, whether these are state, commercial or civic actors. Funding priorities not only determine the focus of the projects that will be funded, but also link particular geographies and topics. 
Moreover, there is an increased focus on the justification of research through its market or government uptake, and its (pathways to) impact. While such 'instructed' research is perfectly explainable and legitimate in itself, it cannot be the only form of knowledge accumulation or the only legitimized interaction between research and practice. Future research and practice could focus on how funding priorities support or disadvantage certain intersections of areas, projects, people, places, topics and concepts. Funders, at the same time, can push for more inclusive research through their calls.

Finally, all research agendas are ideological, and this one is no different. We aim to challenge and question. While we identify a trend towards the broadening and diversification of how heritage planning is understood, heritage planning research or practice can be challenged much more. It is often not very diverse; either in terms of the people involved or in the approaches and projects undertaken and acknowledged. Therefore, we have suggested ways to scrutinize and rethink the role(s) of heritage planning, and the aims we have for and with it. To actively engage with and take seriously worldviews and knowledges constructed outside of the hegemonic discourse, we need to span the boundaries between practices, policies and researches, as well as incorporate intersectional feminist, indigenous, queer, disability or working-class perspectives and critiques.

This is why, as also proposed in Chapter 2 (Kisić), we need to not only ask what gets prioritized in terms of questions and themes, but also how we want to stimulate thinking about and doing research and practice, and who gets to do it and where. The question of how includes rethinking, discussing and reworking the circumstances, rules and frameworks under which our intellectual work proceeds, as well as the agendas and models to which it conforms. Creating a more dynamic relationship between science and policy is essential for responding to current and future societal challenges. But we also need to consider the 'how' of funding models. Different studies challenge current science policies that assume competitive funding to be the best way to boost the quality of science produced. In fact, competitiveness of funding and research quality are negatively correlated (Sandström and Van den Besselaar 2018). The question of who concerns who is deemed appropriate and legitimate to be involved in research or practice, as well as who decides on policy and funding priorities or funding models; who has access to the funding, production and dissemination of knowledge and who is affected by it. But it is also about our own positionality. For example, research is often constructed outside of practice, and vice versa. We acknowledge that, while all four authors of this chapter are moving between those two 'worlds' constantly, we still also do this! As boundary spanners we constantly ask ourselves how science can contribute to policy 
and practice (and vice versa). How can we better facilitate ongoing interactions among research and policy communities to address complex social issues in the field of heritage planning?

Addressing the questions raised here and throughout the book requires structural and institutional change within both academia and heritage and planning practice. Heritage planning can have major impacts on society. Taking seriously the transformative potential of the process of heritage planning, conservation and reuse can help us to reposition and rethink heritage planning, allowing us to centre it within diverse movements for making our world more just, diverse and sustainable. To do so, we need truly challenging research that inspires new pathways and imaginings for the future!

\section{References}

Agyeman, J. (2005), Sustainable Communities and the Challenge of Environmental Justice, New York: NYU Press.

Ahmed, S. (2017), Living a Feminist Life, Durham, NC: Duke University Press.

Anderson, B. (1983), Imagined Communities: Reflections on the Origin and Spread of Nationalism, London: Verso.

Banks, S. and P. Westoby (2019), Ethics, Equity and Community Development, Bristol: Policy Press.

Bhambra, G.K. (2017), 'Brexit, Trump, and "methodological whiteness": on the misrecognition of race and class', The British Journal of Sociology, 68 (S1), S214-32.

Buchczyk, M. and K. Facer (2020), 'The stuff of contention and care: affective materiality and everyday learning in Bristol, UK', City \& Society, 32 (3), 603-23.

Cahuas, M.C. (2019), 'Burned, broke, and brilliant: Latinx community workers' experiences across the Greater Toronto Area's non-profit sector', Antipode, 51 (1), 66-86.

Carter, J. (2010), 'Displacing indigenous cultural landscapes: the naturalistic gaze at Fraser Island World Heritage Area', Geographical Research, 48 (4), 398-410.

CoE (2005), Faro Convention - Framework Convention on the Value of Cultural Heritage for Society; CETS No.199, accessed 3 August 2016 at https://www.coe.int/ en/web/conventions/full-list/-/conventions/treaty/199.

Crooke, E. and T. Maguire (2018), Heritage after Conflict: Northern Ireland, Abingdon, Oxon and New York: Routledge.

Dabiri, E. (2020), Don't Touch My Hair, London: Penguin Books.

Davidson, T. (2016), 'Imperial nostalgia, social ghosts, and Canada's National War Memorial', Space and Culture, 19 (2), 177-91.

Davoudi, S., R. Cowell, I. White et al. (2019), The Routledge Companion to Environmental Planning, Oxon and New York: Routledge.

Dellenbaugh, M., M. Kip, M. Bieniok, A. Müller and M. Schwegmann (2015), Urban Commons: Moving Beyond State and Market, Basel: Birkhäuser.

DeSilvey, C. (2017), Curated Decay: Heritage Beyond Saving, Minneapolis, MN: University of Minnesota Press.

Dicks, B. (2000), Heritage, Place, and Community, Cardiff: University of Wales Press. 
Emejulu, A. (2011), 'The silencing of radical democracy in American community development: the struggle of identities, discourses and practices', Community Development Journal, 46 (2), 229-44.

Erickson, B. (2020), 'Anthropocene futures: linking colonialism and environmentalism in an age of crisis', Environment and Planning D: Society and Space, 38 (1), 111-28.

EU (2019), 'Urban Agenda for the EU', Text, accessed 26 May 2020 at https://ec.europa .eu/futurium/en/urban-agenda.

Ferreira, A. and K.C. von Schönfeld (2020), 'Interlacing planning and degrowth scholarship', DisP - The Planning Review, 56 (1), 53-64.

Foster, S. and C. Iaione (2015), The City as a Commons, SSRN Scholarly Paper ID 2653084, Rochester, NY: Social Science Research Network, 29 August, https://doi .org/10.2139/ssrn.2653084.

Hall, S. (1999), 'Whose heritage? Unsettling "the heritage", reimagining the Postnation', Third Text, 13 (49), 3-13, https://doi.org/10.1080/09528829908576818.

Harvey, D. (2003), 'The right to the city', International Journal of Urban and Regional Research, 27 (4), 939-41.

Healey, P. (1997), Collaborative Planning: Shaping Places in Fragmented Societies, Vancouver: UBC Press.

Hosagrahar, J., J. Soule, L.F. Girard and A. Potts (2016), 'Cultural heritage, the UN Sustainable Development Goals, and the New Urban Agenda', BDC. Bollettino Del Centro Calza Bini, 16 (1), 37-54.

Kaza, N. (2006), 'Tyranny of the median and costly consent: a reflection on the justification for participatory urban planning processes', Planning Theory, 5 (3), 255-70.

Kimmerer, R.W. (2020), Braiding Sweetgrass: Indigenous Wisdom, Scientific Knowledge and the Teachings of Plants, Place of publication not identified: Milkweed Editions.

Kisić, V. (2016), Governing Heritage Dissonance: Promises and Realities of Selected Cultural Policies, Belgrade: European Cultural Foundation (ECF).

Kisić, V. (2018), 'Beyond celebrations and divisions: re-politicizing heritage dissonance in Europe', Economia Della Cultura, 4, 465-78.

Lave, R., P. Mirowski and S. Randalls (2010), 'Introduction: STS and neoliberal science', Social Studies of Science, https://doi.org/10.1177/0306312710378549.

Light, D. (2000), 'An unwanted past: contemporary tourism and the heritage of communism in Romania', International Journal of Heritage Studies, 6 (2), 145-60.

Lowenhaupt Tsing, A. (2017), The Mushroom at the End of the World: On the Possibility of Life in Capitalist Ruins, Princeton, NJ and Oxford: Princeton University Press.

Lynch, K. (2006), 'Neo-liberalism and marketisation: the implications for Higher Education', European Educational Research Journal, https://doi.org/10.2304/eerj .2006.5.1.1.

Macdonald, S. (2010), Difficult Heritage: Negotiating the Nazi Past in Nuremberg and Beyond, Abingdon: Routledge.

Meléndez, J.W. and B. Parker (2019), 'Learning in participatory planning processes: taking advantage of concepts and theories across disciplines', Planning Theory \& Practice, accessed 26 August 2020 at https://www.tandfonline.com/doi/abs/10.1080/ 14649357.2018.1558748.

Milano, C., M. Novelli and J.M. Cheer (2019), 'Overtourism and degrowth: a social movements perspective', Journal of Sustainable Tourism, 27 (12), 1857-75, doi: 10.1080/09669582.2019.1650054

Mouffe, C. (2013), Agonistics: Thinking the World Politically, London and New York: Verso. 
Ostrom, E. (1990), Governing the Commons: The Evolution of Institutions for Collective Action, Cambridge: Cambridge University Press.

Pantazatos, A. (2015), 'The normative foundations of stewardship: care and respect', in T. Ireland and J. Schofield (eds), The Ethics of Cultural Heritage, Springer New York, pp. 127-141.

Pavićević, D. and I. Spasića (2016), 'Contribution to the critique of the project-form', in A. Matković, M. Losoncz, I. Krtolica, Univerzitet u Beogradu and Institut za filozofiju i društvenu teoriju (eds), Thinking beyond Capitalism, Belgrade: University of Belgrade, Institute for Philosophy and Social Theory, pp. 107-18.

Pitts, J. (2019), Afropean: Notes from Black Europe, London: Allen Lane.

Puig de la Bellacasa, M. (2017), Matters of Care: Speculative Ethics in More Than Human Worlds, Minneapolis, MN: University of Minnesota Press.

Rex, B. (2018), From public to 'other-than-public' management: exploring local authority approaches to securing 'publicness' in the case of community asset transfer, Keynote presented at the Organisational Reform and Public Interest Seminar, as organized by Media, Culture, Heritage (MCH), Newcastle University, Newcastle upon Tyne, UK.

Rodríguez-Pose, A. (2018), 'The revenge of the places that don't matter (and what to do about it)', Cambridge Journal of Regions, Economy and Society, 11 (1), 189-209.

Salt, K.N. (2020), 'Imagining futures in the age of twilight', Modern Languages Open, $1,21$.

Sandström, U. and P. Van den Besselaar (2018), 'Funding, evaluation, and the performance of national research systems', Journal of Informetrics, 12 (1), 365-84.

Silverman, H. (2010), Contested Cultural Heritage: Religion, Nationalism, Erasure, and Exclusion in a Global World, New York: Springer Science \& Business Media.

Sinclair-Chapman, V. (2018), '(De)Constructing symbols: Charlottesville, the confederate flag, and a case for disrupting symbolic meaning', Politics, Groups, and Identities, 6 (2), 316-23.

Song, L.K. (2015), 'Race, transformative planning, and the just city', Planning Theory, $14(2), 152-73$.

Tolia-Kelly, D.P., E. Waterton and S. Watson (eds) (2017), Heritage, Affect and Emotion: Politics, Practices and Infrastructures, London and New York: Routledge and Taylor \& Francis Group.

Tosch, J. (2013), 'Black Heritage Tours Amsterdam \& New York', accessed 1 July 2020 at http://www.blackheritagetours.com/.

Tunbridge, J.E. and G.J. Ashworth (1996), Dissonant Heritage: The Management of the Past as a Resource in Conflict, Chichester: Wiley.

Ugwuanyi, J.K. (2020), 'Time-space politics and heritagisation in Africa: understanding where to begin decolonisation', International Journal of Heritage Studies, 27 (4), $356-74$.

UNESCO (2011), Recommendation on the Historic Urban Landscape, Paris: UNESCO World Heritage Centre, accessed 25 January 2018 at http://whc.unesco.org/uploads/ activities/documents/activity-638-98.pdf.

UN-HABITAT (2016), 'The New Urban Agenda', accessed 26 May 2020 at http:// habitat3.org/the-new-urban-agenda/.

Veldpaus, L. and J. Pendlebury (2019), 'Heritage as a vehicle for development: the case of Bigg Market, Newcastle upon Tyne', Planning Practice \& Research, 1-15, doi: 10.1080/02697459.2019.1637168.

Veldpaus, L., F. Fava and D. Brodowicz (2019), Mapping of Current Heritage Re-use Policies and Regulations in Europe. Complex Policy Overview of Adaptive Heritage 
Re-use, OpenHeritage: Deliverable 1.2, Newcastle upon Tyne, England, 254, December.

Virdee, S. (2019), 'Racialized capitalism: an account of its contested origins and consolidation', The Sociological Review, 67 (1), 3-27.

Wollentz, G., S. May, C. Holtorf and A. Högberg (2020), 'Toxic heritage: uncertain and unsafe', in R. Harrison (ed.), Heritage Futures: Comparative Approaches to Natural and Cultural Heritage Practices, accessed 27 August 2020 at https://www.uclpress.co .uk/products/125034.

Wong, C.U.I. (2013), 'The sanitization of colonial history: authenticity, heritage interpretation and the case of Macau's tour guides', Journal of Sustainable Tourism, 21 (6), 915-31. 